\title{
PENGARUH SUASANA TOKO DAN CITRA TOKO TERHADAP KEPUTUSAN PEMBELIAN KONSUMEN PADA TOKO BUKU RAMEDIA DI KOTA PALU
}

\author{
Andhika Dwitama \\ Suardi \\ Ira Nuriya Santi \\ Jurusan Manajemen, Fakultas Ekonomi, Universitas Tadulako \\ Email: andhika_dwitama96@yahoo.com
}

\begin{abstract}
The purpose of this study is to know and analyze the influence of store atmosphere (X1) and store image (X2) simultaneously and partially significant effect on purchasing decision of consumer (Y) at Bookstore Ramedia in Palu City. This type of research is causal research. The population of this study is the people of Palu City who were / were buying at Ramedia Bookstore. Sampling technique using purposive sampling with sample number 90 people. The analysis tool used is multiple linear regression analysis. Based on the result of multiple linear regression analysis, it was found that store atmosphere variables (X1) and store image (X2) simultaneously significant influence consumer purchasing decision $(Y)$ at Ramedia Bookstore in Palu with significant value 0.001 below <0.05. Store atmosphere variables $(X 1)=0.021$ and store image $(X 2)=0.042$ partially significant effect on purchasing decision of consumer in Ramedia Bookstore in Palu City.
\end{abstract}

Keywords: store atmosphere, store image, purchasing decision

\begin{abstract}
ABSTRAK
Tujuan penelitian ini adalah untuk mengetahui dan menganalisis pengaruh suasana toko $\left(\mathrm{X}_{1}\right)$ dan citra toko $\left(\mathrm{X}_{2}\right)$ secara simultan dan parsial berpengaruh signifikan terhadap keputusan pembelian konsumen $(\mathrm{Y})$ pada Toko Buku Ramedia di Kota Palu. Jenis penelitian ini yaitu penelitian kausal. Populasi penelitian ini adalah masyarakat Kota Palu yang pernah/sedang membeli di Toko Buku Ramedia. Teknik penarikan sampel menggunakan purposive sampling dengan jumlah sampel 90 orang. Alat analisis yang digunakan adalah analisis regresi linear berganda. Berdasarkan hasil analisis regresi linear berganda didapatkan hasil bahwa variabel suasana toko $\left(\mathrm{X}_{1}\right)$ dan citra toko $\left(\mathrm{X}_{2}\right)$ secara simultan berpengaruh signifikan terhadap keputusan pembelian konsumen (Y) pada Toko Buku Ramedia di Kota Palu dengan nilai signifikan 0.001 dibawah $<0.05$. Variabel suasana toko $\left(\mathrm{X}_{1}\right)=0.021$ dan citra toko $\left(\mathrm{X}_{2}\right)=0.042$ secara parsial berpengaruh signifikan terhadap keputusan pembelian konsumen pada Toko Buku Ramedia di Kota Palu.
\end{abstract}

Kata Kunci: Suasana toko, Citra toko, Keputusan pembelian

\section{PENDAHULUAN}

Seiring perkembangan zaman yang cepat dan tanggap akan teknologi ini, masyarakat sangat diharuskan untuk banyak mengetahui informasi yang sesuai dengan perkembangan zaman, sehingga diharapkan masyarakat memiliki informasi dan pengetahuan yang lebih pada zaman yang semakin berkembang dan modern ini. Buku adalah alat yang mempunyai banyak informasi di dalamnya, sehingga dapat berperan meningkatkan kemampuan aktivitas atau cara berpikir dari setiap individu. buku memiliki peranan yang sangat penting dalam setiap kehidupan manusia, melalui buku masyarakat dapat mengejar ketertinggalan pengetahuannya dengan singkat.

Buku merupakan salah satu jawaban bagi mereka yang ingin berkembang dan bereksplorasi tentang pengetahuan yang dimiliki, karena buku merupakan salah satu media informasi yang sangat berperan aktif dengan ilmu pengetahuan masyarakat. Banyak buku yang dapat memberikan pengetahuan yang cukup bagi individu, misalnya komik, buku motivasi, biografi, buku agama dan buku pengetahuan lainnya. 
Berman dan Evans dalam Erlangga dan Achmad (2012:60) membagi elemen-elemen suasana toko ke dalam empat elemen, yaitu: exterior, general interior, store layout, dan interior display. Keempat elemen tersebut, masing-masing memiliki peran yang sangat erat dalam mempengaruhi keputusan pembelian konsumen. Menurut Ma'ruf, (2005:195) exterior adalah elemen yang paling vital dalam faktor suasana toko karena elemen ini merupakan kesan pertama yang dilihat dan dirasakan oleh konsumen. Konsumen harus dapat merasa nyaman dengan penglihatan pertamanya pada toko yang akan dilihatnya. Kesan nyaman akan mengundang minat konsumen untuk memasuki toko dan memungkinkan untuk melakukan pembelian. General interior sangat berarti dalam menarik konsumen untuk melakukan pembelian, karena itu suatu toko harus mampu menimbulkan persepsi yang bagus pada konsumen. Store layout adalah tata letak produk, kasir dan arus lalu lalang konsumen dalam toko. Pengelola toko harus mempunyai rencana dalam penentuan lokasi dan fasilitas toko dan memanfaatkan ruangan toko yang ada seefektif mungkin. Layout yang baik akan mampu mengundang konsumen untuk betah berkeliling lebih lama di dalam toko. Menurut Ma'Ruf (2005:205) interior display merupakan salah satu dari alat promosi penjualan yang mempunyai fungsi untuk menarik perhatian pelanggan agar dapat melakukan pembelian. Tujuan utama interior display adalah untuk meningkatkan penjualan dan laba suatu toko, jika tampilan interior suatu toko menarik maka akan mempengaruhi minat konsumen untuk melakukan pembelian ke toko tersebut.

Menurut Sopiah dan Syihabudhin (2008) citra toko yang baik dapat menjamin kelangsungan hidup perusahaan untuk bertahan terhadap persaingan dalam membentuk pelanggan yang loyal. Beberapa komponen citra toko yang mempengaruhi keputusan pembelian konsumen, diantaranya adalah lokasi, produk, harga, pelayanan dan fasilitas fisik. Lokasi merupakan tempat di mana toko tersebut melakukan kegiatan fisiknya. Suatu lokasi disebut strategis bila berada dipusat kota, kepadatan populasi, kemudahan mencapainya menyangkut kemudahan transportasi umum, kelancaran lalu lintas dan arahnya tidak membingungkan konsumen, kelancaran arus pejalan kaki dan sebagainya. Produk yang kualitasnya selalu terjaga dan lengkap merupakan salah satu unsur yang dapat mempengaruhi konsumen dalam melakukan keputusan pembelian. Harga yang murah dan cukup terjangkau memungkinkan konsumen untuk melakukan pembelian. Pelayanan yang baik dari karyawan dapat mempengaruhi konsumen membeli, layanan yang cepat dan pengetahuan tentang produk yang dijual dapat membantu konsumen dalam mencari produk yang diinginkan. Fasilitas fisik toko yang menarik dan ruangan yang ber-ac membuat konsumen merasa lebih betah dan nyaman berada di dalam toko, hal itu juga mempengaruhi keputusan pembelian konsumen. Berdasarkan hal tersebut, maka tujuan penelitian ini adalah:

1. Untuk mengetahui pengaruh suasana toko dan citra toko terhadap keputusan pembelian konsumen pada toko buku Ramedia di Kota Palu.

2. Untuk mengetahui pengaruh suasana toko terhadap keputusan pembelian konsumen pada toko buku Ramedia di Kota Palu.

3. Untuk mengetahui pengaruh citra toko terhadap keputusan pembelian konsumen pada toko buku Ramedia di Kota Palu.

\section{KAJIAN LITERATUR DAN PENGEMBANGAN HIPOTESIS Pengertian Suasana Toko}

Menurut Utami (2006:217) suasana toko (store atmosphere) adalah kombinasi dari karakteristik fisik toko seperti arsitektur, tata letak, pencahayaan, pemajangan, warna, temperatur, musik, aroma yang secara menyeluruh akan menciptakan image atau citra dalam benak konsumen. Melalui suasana toko yang sengaja diciptakan, ritel berupaya mengomunikasikan informasi yang terkait dengan layanan, harga, maupun ketersediaan barang dagangan yang bersifat fashionable. 
Menurut Vinci (2009:55) suasana toko (store atmosphere) adalah seluruh efek estetika dan emosional yang diciptakan melalui ciri fisik toko, di mana semuanya berhubungan dengan panca indera (penglihatan) dari konsumen. Menurut Foster (2008:61) suasana setiap toko mempunyai tata letak fisik yang memudahkan/menyulitkan untuk berputar-putar di dalamnya. Setiap toko mempunyai tampilan yang berbeda-beda baik itu kotor, menarik, megah, dan suram. Suatu toko harus membentuk suasana terencana yang sesuai dengan pasar sasarannya dan dapat menarik konsumen untuk membeli di toko tersebut.

\section{Dimensi Suasana Toko}

Dimensi variabel suasana toko menggunakan teori dari Berman dan Evans dalam Fuad (2010:3), yaitu:

1. Store exterior, yaitu bagian depan toko yang mencerminkan kemantapan dan kekokohan spirit perusahaan dan sifat kegiatan yang ada di dalamnya, serta dapat menciptakan kepercayaan dan goodwill bagi konsumen.

2. General interior, yaitu bagian dalam toko yang dapat menarik perhatian para konsumen dan membantu mereka agar mudah mengamati, memeriksa dan memilih barang-barang, dan akhirnya melakukan pembelian ketika konsumen masuk ke dalam toko.

3. Store layout, yaitu rencana untuk menentukan lokasi tertentu dan pengaturan dari jalan/gang di dalam toko yang cukup lebar yang memudahkan para konsumen untuk berlalu lalang di dalamnya.

4. Interior display, yaitu tanda-tanda yang digunakan untuk memberikan informasi kepada konsumen untuk mempengaruhi suasana lingkungan toko, dengan tujuan utama untuk meningkatkan penjualan dan laba toko tersebut.

\section{Pengertian Citra Toko}

Menurut Utami (2008:15) citra sebuah toko atau ritel dapat dibangun berdasarkan karakteristik barang dagangan yang ditawarkan untuk dibeli oleh pelanggan. Pada umumnya produk atau barang dagangan (merchandise) dengan kualitas yang baik dan ketersediaan produk yang bervariasi akan memberikan kepuasan dan citra tersendiri bagi konsumen. Menurut Vinci (2009:46) citra toko merupakan kepribadian dari sebuah toko. Citra yang dimaksud disini adalah bagaimana konsumen memandang dan merasakan lingkungan dari sebuah toko.

Citra toko merupakan kepribadian toko, yaitu menggambarkan apa yang di lihat dan dirasakan oleh konsumen terhadap toko tersebut. Menurut Sopiah dan Syihabudhin (2008:138) citra toko merupakan pandangan/persepsi masyarakat terhadap nama atau produk toko secara efektif, baik dari segi nilai, kualitas, dan harga. Jadi, citra toko dari suatu tempat berbelanja menjadi penting bagi konsumen, karena konsumen umumnya lebih memilih pusat perbelanjaan yang memberikan citra yang baik pada mereka.

Berdasarkan pengertian dari beberapa para pakar di atas maka dapat disimpulkan bahwa citra toko merupakan pandangan masyarakat terhadap kepribadian sebuah toko yang dapat di lihat dan dirasakan sehingga memberikan kepuasan tersendiri bagi konsumen yang datang untuk melakukan pembelian.

\section{Dimensi Citra Toko}

Dimensi variabel citra toko menggunakan teori dari Berman dan Evans dalam Foster (2008:51), yaitu: 
1. Lokasi, akan mempengaruhi jumlah dan jenis konsumen yang akan tertarik untuk datang ke lokasi yang strategis, mudah dijangkau oleh sarana transportasi yang ada, serta kapasitas parkir yang cukup memadai bagi konsumen.

2. Produk, merupakan perencanaan dan pengendalian dalam pembelian dan penjualan barang dan jasa untuk mencapai tujuan yang telah ditetapkan pengecer.

3. Harga, tingkat harga pada suatu toko dapat mempengaruhi cara berpikir konsumen terhadap unsurunsur lain dari bauran ritel.

4. Pelayanan, merupakan suatu keinginan konsumen untuk dilayani dan pelayanan produk yang akan dibeli konsumen.

5. Fasilitas fisik, merupakan faktor penentu dalam mendominasi pangsa pasar yang diinginkan oleh perusahaan, karena penguasaan pasar dapat dicapai apabila perusahaan mendapat kedudukan yang baik sehingga dapat menciptakan citra perusahaan bagi para konsumennya.

\section{Pengertian Keputusan Pembelian}

Menurut Kotler dan Amstrong (2008:179) keputusan pembelian adalah tahap dimana proses pengambilan keputusan pembeli dimana konsumen benar-benar membeli, pengambilan keputusan merupakan suatu kegiatan individu yang secara langsung terlibat dalam mendapatkan dan mempergunakan barang yang ditawarkan oleh produsen.

Menurut Winardi (2010:200) keputusan pembelian konsumen merupakan titik suatu pembelian dari proses evaluasi. Selanjutnya, Peter dan Olson (2009:162) menyatakan keputusan pembelian adalah proses pengintegrasian yang dikombinasikan untuk mengevaluasi dua atau lebih perilaku alternatif dan memilih salah satu diantaranya.

Berdasarkan pengertian di atas dapat disimpulkan bahwa keputusan pembelian konsumen adalah suatu proses pengambilan keputusan berdasarkan kebutuhan dan keinginan yang telah dibentuk oleh ketertarikan karena adanya stimulus (rangsangan) tertentu dari internal maupun eksternal individu itu sendiri.

\section{Proses Pengambilan Keputusan Konsumen}

Tahapan-tahapan dalam proses pengambilan keputusan pembelian yang dikemukakan oleh Kotler dan Keller (2009:184), yaitu:

1. Pengenalan masalah, tahap ini merupakan fase pengenalan tentang apa yang dibutuhkan oleh pembeli tersebut, hal ini muncul sebagai refleksi dari rangsangan internal atau eksternal, secara umum biasanya dapat di lihat dari munculnya tren yang terbaru pada setiap produk sehingga membuat konsumen memilih untuk mencari bentuk produk yang lagi trennya berkembang pada saat itu.

2. Pencarian informasi, konsumen mengidentifikasi apa yang menjadi kebutuhannya, maka tahap selanjutnya konsumen tersebut berusaha mencari informasi tentang produk, merek, jumlah pembelian yang dilakukan, serta bagaimana dia menggunakan barang tersebut.

3. Evaluasi alternatif, tahap ini konsumen berusaha mengevaluasi di antara sekian banyak informasi yang menyangkut tentang pilihan produk dan merek, secara umum dapat dilihat pada pemilihan merek yang terbaik.

4. Keputusan pembelian, konsumen melewati beberapa pertimbangan rasional tentang serentetan pilihan produk, maka tahap selanjutnya konsumen memutuskan untuk memilih satu produk yang menjadi pilihannya. 
5. Perilaku pasca pembelian, konsumen menggunakan barang yang telah di beli, maka akan memunculkan dua jenis tanggapan dari konsumen tentang nilai dari suatu produk yaitu puas dan tidak memuaskan.

\section{Kerangka Pemikiran}

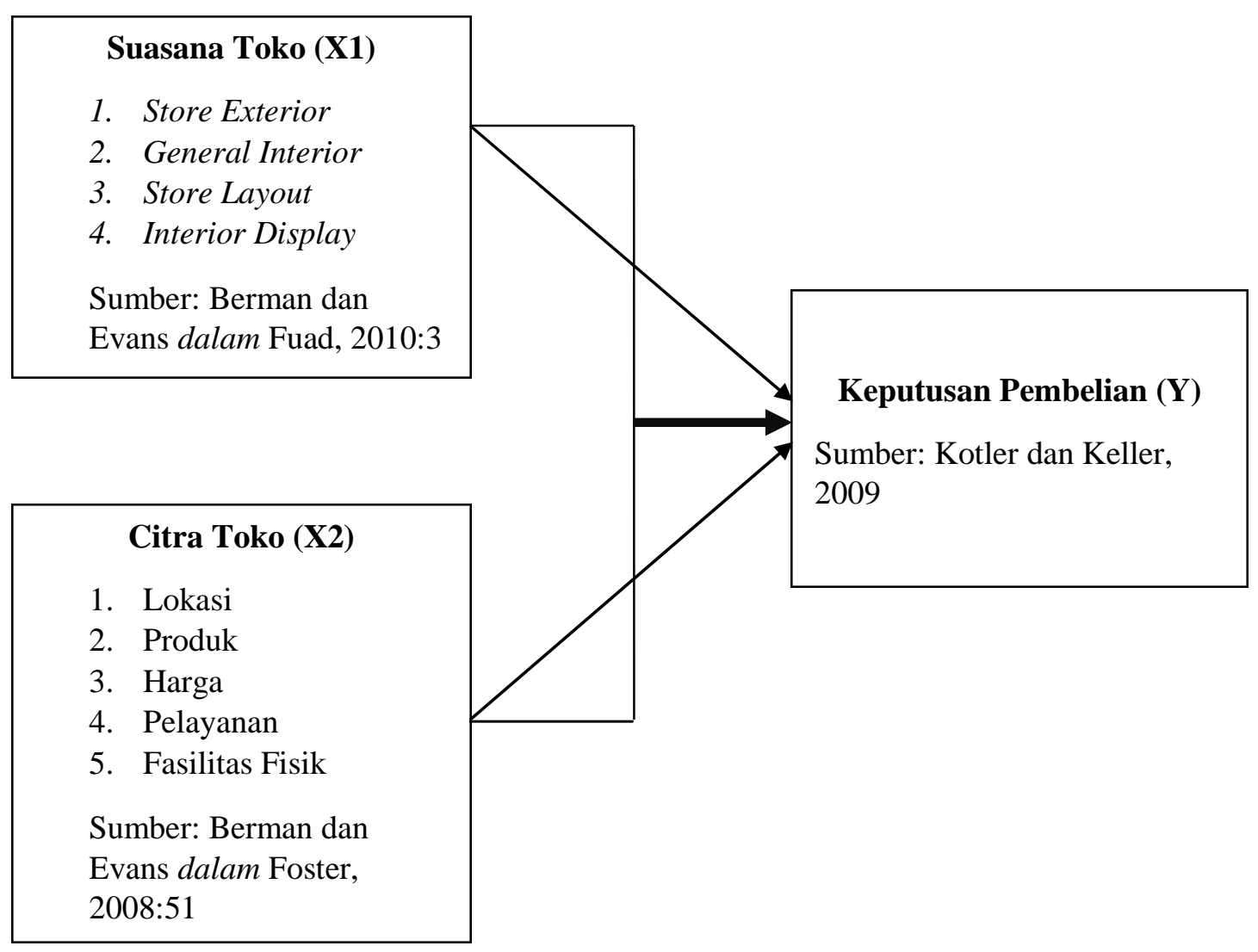

Gambar 1

Kerangka Pemikiran

\section{Hipotesis}

Berdasarkan latar belakang dan tujuan serta dukungan teori di atas maka hipotesis dalam penelitian ini adalah sebagai berikut:

1. Suasana toko dan citra toko secara simultan berpengaruh signifikan terhadap keputusan pembelian konsumen pada toko buku Ramedia di Kota Palu.

2. Suasana toko berpengaruh signifikan terhadap keputusan pembelian konsumen pada toko buku Ramedia di Kota Palu.

3. Citra toko berpengaruh signifikan terhadap keputusan pembelian konsumen pada toko buku Ramedia di Kota Palu.

\section{METODE PENELITIAN}

Tipe penelitian yang digunakan dalam penelitian ini adalah penelitian kausal. Menurut Malhotra (2009:100) penelitian kausal merupakan salah satu jenis riset konsklusif yang mempunyai tujuan utama untuk mendapatkan bukti hubungan sebab akibat. Penelitian ini menggunakan pendekatan kuantitatif 
dimana penelitian kuantitatif lebih menekankan pada pengujian teori-teori melalui pengukuran variabelvariabel penelitian dengan angka dan melakukan analisis dengan prosedur statistik agar diketahui apakah penelitian ini berhasil atau tidak.

Penelitian ini dilaksanakan di Kota Palu dengan lokasi penelitian pada toko buku Ramedia yang berada di Jalan Sultan Hasanuddin No. 40, Palu. Penulis memilih toko buku Ramedia karena toko buku Ramedia sudah dikenal oleh masyarakat Kota Palu. Untuk mengumpulkan data, teknik pengumpulan data yang digunakan terdiri dari:

1. Observasi, yaitu metode pengumpulan data dengan melakukan pengamatan langsung terhadap objek yang akan atau sedang diteliti kemudian dilakukan pencatatan tentang apa yang sedang diamati.

2. Kuesioner, yaitu instrumen untuk pengumpulan data, dimana partisipasi atau responden untuk dijawabnya. Kuesioner merupakan teknik pengumpulan data yang efisien karena dapat diukur dan mengetahui apa yang diharapkan dari responden.

3. Wawancara, yaitu metode yang dipakai oleh peneliti untuk mengumpulkan informasi mengenai variabel yang diteliti, dengan cara tanya jawab secara singkat dengan responden yang terpilih sebagai sampel.

Kemudian dalam penelitian ini jumlah populasi tidak diketahui secara pasti, maka metode pengambilan sampel dilakukan dengan menggunakan teknik purposive sampling. Menurut Sugiyono (2014:156) teknik purposive sampling adalah teknik penentuan sampel dengan pertimbangan tertentu. Alasan menggunakan teknik purposive sampling adalah karena tidak semua sampel memiliki kriteria yang sesuai dengan peneliti tentukan.

Metode analisis yang digunakan dalam penelitian ini adalah dengan pendekatan statistik deskriptif melalui penggunaan alat analisis regresi linear berganda (Multiple Linear Regression). Menurut Sugiyono (2014) model umum bentuk persamaan alat analisis statistik parametrik regresi linear berganda dapat digambarkan sebagai berikut :

$$
\mathbf{Y}=\mathbf{a}+\mathbf{b}_{1} \mathbf{X}_{1}+\mathbf{b}_{2} \mathbf{X}_{2}
$$

Keterangan:

$$
\begin{array}{ll}
Y & =\text { Keputusan pembelian } \\
a & =\text { Konstanta } \\
b_{1} & =\text { Koefisien regresi suasanatoko } \\
b_{2} & =\text { Koefisien regresi citra toko } \\
X_{1} & =\text { Suasana toko } \\
X_{2} & =\text { Citra took }
\end{array}
$$

\section{HASIL DAN PEMBAHASAN}

\section{HASIL PENELITIAN}

\section{Tabel 1}

Hasil Regresi Linear Berganda

\begin{tabular}{|l|c|c|c|c|c|}
\hline \multirow{2}{*}{ Variabel Independen } & \multicolumn{1}{|c|}{ Unstandardized Coefficients } & Standardized Coefficients & t & Sig \\
\cline { 2 - 6 } & $\mathbf{B}$ & Standar Error & Beta & & \\
\hline $\mathrm{C}=$ Costanta & 1.533 & .745 & & 2.058 & .043 \\
\hline Suasana Toko $\left(\mathrm{X}_{1}\right)$ & .343 & .146 & .246 & 2.348 & .021 \\
\hline Citra Toko $\left(\mathrm{X}_{2}\right)$ & .352 & .171 & .216 & 2.064 & .042 \\
\hline Multiple $\mathrm{R}=0.375$ & Sig. $\mathrm{F}=0.001$ & & \\
$\mathrm{R}$ Square $\left(\mathrm{R}^{2}\right)=0.141$ & \multicolumn{5}{|c}{} \\
\hline
\end{tabular}


Berdasarkan nilai dari Tabel 1, maka persamaan regresi dapat dirumuskan sebagai berikut:

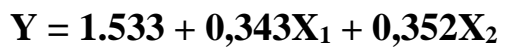

Persamaan di atas menunjukkan, variabel independen yang dianalisis yaitu variabel $\left(\mathrm{X}_{1}\right.$ dan $\left.\mathrm{X}_{2}\right)$ memberi pengaruh positif terhadap variabel dependen $(\mathrm{Y})$, yaitu keputusan pembelian konsumen pada toko buku Ramedia di Kota Palu. Penjelasan bentuk persamaan tersebut dapat dilihat berikut ini:

1. Untuk nilai konstanta sebesar 1,533 berarti apabila variabel suasana toko $\left(\mathrm{X}_{1}\right)$ dan citra toko $\left(\mathrm{X}_{2}\right)$ nilainya 0 , maka variabel keputusan pembelian (Y) nilainya tetap positif yaitu 1.533.

2. Koefisien regresi variabel suasana toko $\left(X_{1}\right)$ sebesar 0.343 , artinya jika suasana toko meningkat, maka keputusan pembelian konsumen pada toko buku di Ramedia Kota Palu naik sebesar 0.343 atau 34.3\%.

3. Koefisien regresi variabel citra toko $\left(\mathrm{X}_{2}\right)$ sebesar 0.352 , artinya jika citra toko meningkat, maka keputusan pembelian konsumen pada toko buku di Ramedia Kota Palu naik sebesar 0.352 atau 35.2\%.

Berdasarkan Tabel 1, dapat dilihat pengaruh hasil uji determinasi $R$ Square $\left(\mathrm{R}^{2}\right)$ sebesar 0.141. Nilai tersebut dapat diartikan bahwa semua variabel bebas yakni suasana toko dan citra toko mempunyai kontribusi sebesar $14.1 \%$ terhadap variabel terikat yaitu keputusan pembelian konsumen. Sedangkan sisanya $(100 \%-14.1 \%=85.9 \%)$, dipengaruhi oleh variabel lain yang tidak diteliti. Faktor yang menyebabkan nilai $\mathrm{R}$ Square $\left(\mathrm{R}^{2}\right)$ kecil adalah minat baca masyarakat Kota Palu yang masih rendah, hal ini dapat mempengaruhi tingkat pendapatan toko buku Ramedia. Faktor lainnya masyarakat Kota Palu kurang berminat datang ke toko buku Ramedia untuk melakukan pembelian dikarenakan suasana toko yang kurang menarik. Contoh lainnya adalah buku terbitan terbaru yang belum tersedia, yaitu buku Philip Kotler yang edisi tahun 2016, hal ini harus diperhatikan oleh pihak toko buku Ramedia karena dosen dan mahasiswa sekarang sangat diharuskan untuk mencari buku yang terbitan baru.

\section{Uji F}

Berdasarkan Tabel 1 terlihat nilai signifikansi $\mathrm{F}=0,001<0,05$, berarti variabel bebas secara bersamasama (simultan) berpengaruh signifikan terhadap variabel terikat, artinya bahwa variabel suasana toko dan citra toko secara bersama-sama (simultan) berpengaruh positif dan signifikan terhadap variabel keputusan pembelian konsumen pada toko buku Ramedia di Kota Palu. Hipotesis yang menyatakan bahwa suasana toko dan citra toko berpengaruh positif dan signifikan terhadap keputusan pembelian konsumen pada toko buku Ramedia di Kota Palu berdasarkan uji-F hasilnya terbukti.

\section{Uji t}

Adapun hasil uji hipotesis secara parsial dapat dilihat sebagai sebagai berikut:

1. Suasana Toko (X1)

Berdasarkan Tabel 1, hasil pengujian variabel suasana toko diperoleh tingkat signifikansi sebesar 0,021 $<0,05$. Artinya bahwa variabel suasana toko berpengaruh positif dan signifikan terhadap keputusan pembelian konsumen pada toko buku Ramedia di Kota Palu. Hipotesis yang menyatakan bahwa suasana toko berpengaruh positif signifikan terhadap keputusan pembelian konsumen pada toko buku Ramedia di Kota Palu berdasarkan uji-t hasilnya terbukti.

2. Citra Toko (X2)

Berdasarkan Tabel 1, hasil pengujian variabel citra toko diperoleh tingkat signifikansi sebesar 0,042 > 0,05. Artinya bahwa variabel citra toko berpengaruh positif dan signifikan terhadap keputusan pembelian konsumen pada toko buku Ramedia di Kota Palu. Hipotesis yang menyatakan bahwa citra 
toko berpengaruh positif dan signifikan terhadap keputusan pembelian konsumen pada toko buku

Ramedia di Kota Palu berdasarkan uji-t hasilnya terbukti.

\section{PEMBAHASAN}

\section{Pengaruh Suasana Toko $\left(X_{1}\right)$ dan Citra Toko $\left(X_{2}\right)$ Terhadap Keputusan Pembelian $(Y)$ Toko Buku Ramedia di Kota Palu}

Store atmosphere terbukti dapat digunakan sebagai salah satu sarana komunikasi yang memberikan dampak positif dan menguntungkan apabila mampu dibuat sedemikian menarik sehingga memicu emosi pengunjung yang pada akhirnya melakukan pembelian. Citra toko yang baik adalah bagaimana pelanggan menginterpretasikan pesan dan komunikasi yang ditawarkan kepada pelanggan, yaitu bagaimana persepsi pelanggan toko terhadap produk yang tersedia di dalam toko itu sendiri dan pengalaman yang diharapkan ketika berbelanja di dalam toko tersebut.

Berdasarkan hasil penelitian yang telah dilakukan pada toko buku Ramedia di Kota Palu diketahui bahwa variabel suasana toko dan citra toko berpengaruh signifikan secara simultan terhadap keputusan pembelian konsumen pada toko buku Ramedia di Kota Palu. Pihak toko buku Ramedia sudah mengelola suasana toko yang baik sehingga membuat konsumen mendapatkan kepuasan saat melakukan pembelian dan toko buku Ramedia sudah mampu membangun citra toko yang positif di mata konsumen.

Hasil penelitian ini mendukung penelitian yang pernah dilakukan oleh Vitta Maretha dan Engkos Achmad Kuncoro (2011) dengan judul "Pengaruh Store Atmosphere dan Store Image terhadap Keputusan Pembelian Konsumen Pada Toko Buku Gramedia Pondok Indah”, yang menyimpulkan bahwa store atmosphere dan store image berpengaruh positif terhadap keputusan pembelian pada toko buku Gramedia Pondok Indah.

\section{Pengaruh Suasana Toko ( $\left.\mathrm{X}_{1}\right)$ Terhadap Keputusan Pembelian (Y) Toko Buku Ramedia di Kota Palu}

Suasana toko merupakan salah satu elemen penting dari bauran eceran yang mampu mempengaruhi proses keputusan pembelian konsumen. Hasil penelitian Nurirfani (2014: 98) mengatakan keputusan pembelian konsumen tidak hanya memberi respon terhadap barang dan jasa yang ditawarkan oleh pengecer, tetapi juga memberikan respon terhadap lingkungan pembelian yang menyenangkan bagi konsumen, sehingga konsumen tersebut memilih toko yang disukai dan melakukan pembelian. Mengetahui dan memahami suasana toko bukanlah hal yang mudah karena suasana toko merupakan kombinasi dari hal-hal yang bersifat emosional.

Berdasarkan hasil penelitian yang telah dilakukan, diketahui bahwa variabel suasana toko berpengaruh signifikan secara parsial terhadap keputusan pembelian konsumen pada toko buku Ramedia di Kota Palu. Hasil uji t yang menunjukkan bahwa tingkat signifikansi t yang diperoleh sebesar $0,021<\alpha 0,05$. Teori yang dikemukakan oleh Utami (2006:117) mendefinisikan bahwa suasana merupakan kombinasi karakteristik fisik yang bertujuan untuk merespon emosional dan persepsi pelanggan untuk mempengaruhi keputusan pelanggan dalam membeli barang.

Hasil penelitian ini mendukung penelitian yang pernah dilakukan oleh Widyanto, Yulianto dan Sunarti (2014) dengan judul "Pengaruh Store Atmosphere terhadap Keputusan Pembelian (Survei pada Konsumen Distro Planet Surf Mall Olympic Garden Kota Malang)", yang menyimpulkan bahwa store atmosphere yang terdiri dari exterior, general interior, store layout, dan interior display berpengaruh positif terhadap keputusan pembelian konsumen Distro Planet Surf Mall Olympic Garden Kota Malang. Berdasarkan hasil tersebut dapat dinyatakan bahwa store atmosphere merupakan suatu strategi pemasaran yang dapat diimplementasikan oleh sebuah badan usaha bisnis dalam upaya untuk memberikan daya tarik pada para konsumen untuk melakukan tindakan pembelian. 


\section{Pengaruh Citra Toko ( $\left.\mathbf{X}_{2}\right)$ Terhadap Keputusan Pembelian (Y) Toko Buku Ramedia di Kota Palu}

Store image merupakan salah satu alat yang terpenting bagi peritel untuk menarik dan memenuhi kepuasan konsumen. Konsumen menilai sebuah toko berdasarkan pengalaman mereka atas toko tersebut. Sebagai hasilnya beberapa toko akan menetap dalam benak konsumen apabila ia merasa puas akan toko tersebut sementara toko yang lain ia tidak akan pernah dipertimbangkan sama sekali (Yudatama dkk., 2012). Citra toko yang baik membuat konsumen akan menjadi percaya untuk membeli produk di toko tersebut. Teori dari Simamora (2001:106) mengatakan bahwa minat beli (niat beli) terhadap suatu produk timbul karena adanya dasar kepercayaan terhadap produk yang diiringi dengan kemampuan untuk membeli produk.

Berdasarkan hasil penelitian yang telah dilakukan, diketahui bahwa variabel citra toko berpengaruh signifikan secara parsial terhadap keputusan pembelian konsumen pada toko buku Ramedia di Kota Palu. Hasil uji t yang menunjukkan bahwa tingkat signifikansi t yang diperoleh sebesar $0,042<\alpha 0,05$. Teori yang dikemukakan oleh Sopiah dan Syihabudhin (2008:138) mendefinisikan bahwa image sebuah toko terhadap konsumen dapat diciptakan dengan pembentukan citra toko melalui menyajikan produk yang lengkap dan berkualitas, menetapkan harga dengan wajar, tata ruang yang nyaman serta customer service yang sesuai dengan keinginan konsumen.

Hasil penelitian ini mendukung penelitian yang pernah dilakukan oleh Irawati dan Edwar (2013) dengan judul "Pengaruh Citra Toko terhadap Keputusan Pembelian Konsumen pada Amanah Swalayan Rengel", yang menyimpulkan bahwa citra toko yang terdiri dari lokasi, produk, harga, pelayanan dan fasilitas fisik berpengaruh positif dan signifikan terhadap keputusan pembelian konsumen Amanah Swalayan Rengel Surabaya.

\section{KESIMPULAN DAN SARAN}

\section{Kesimpulan}

1. Suasana toko dan citra toko berpengaruh secara simultan terhadap keputusan pembelian konsumen pada toko buku Ramedia di Kota Palu.

2. Suasana toko berpengaruh signifikan terhadap keputusan pembelian konsumen pada toko buku Ramedia di Kota Palu.

3. Citra toko berpengaruh signifikan terhadap keputusan pembelian konsumen pada toko buku Ramedia di Kota Palu.

\section{Saran}

1. Pada variabel suasana toko, nilai mean terendah terdapat pada dimensi store exterior sehingga disarankan kepada pihak toko buku Ramedia agar lebih meningkatkan tampilan store exterior terutama tempat parkir kendaraan. Hal ini dapat dilakukan dengan menempatkan juru parkir sehingga konsumen dapat berbelanja dengan tenang.

2. Pada variabel citra toko, nilai mean terendah terdapat pada dimensi fasilitas fisik sehingga disarankan kepada pihak toko buku Ramedia agar lebih meningkatkan fasilitas fisik terutama pada eksterior bangunan. Hal ini dapat dilakukan dengan memperindah tampilan depan toko sehingga membuat konsumen tertarik berbelanja di toko buku Ramedia.

3. Tingkat $R$ Square $\left(\mathrm{R}^{2}\right)$ yang rendah dalam penelitian ini menunjukkan bahwa variabel lain mempunyai pengaruh yang lebih besar terhadap keputusan pembelian sehingga disarankan untuk penelitian selanjutnya menggunakan variabel lain dalam penelitian ini. 


\section{REFERENSI}

Bilson, Simamora. (2001). Memenangkan Pasar dengan Pemasaran Efektif dan Profitabel. Edisi pertama. Jakarta: PT. Gramedia Pustaka Umum

Erlangga, Andi dan Achmad Fauzi. (2012). Suasana Toko dalam Menciptakan Emosi dan Pengaruhnya Terhadap Keputusan Pembelian. Jurnal Bisnis dan Ekonomi, Vol. 6, No. 1, Hal. 60-87.

Foster, Bob. (2008). Manajemen Ritel. Bandung: Alfabeta.

Fuad, Muhammad. (2010). Store Atmosphere dan Perilaku Pembelian Konsumen di Toko Buku Gramedia Malang. Jurnal Manajemen Pemasaran Modern, Vol. 2, No. 1, Hal. 1-14.

Irawati, Winaika dan Muhammad Edwar. (2013). Pengaruh Citra Toko Terhadap Keputusan Pembelian Konsumen Pada Amanah Swalayan Rengel. Universitas Negeri Surabaya.

Kotler, Philip dan Gary Amstrong. (2008). Prinsip-prinsip Pemasaran, Edisi 12 Jilid 1. Jakarta: Erlangga Kotler, Philip dan Kevin Lane Keller. (2009). Manajemen Pemasaran, Edisi 13 Jilid 1. Jakarta: Erlangga Malhotra, N. K. (2009). Riset Pemasaran, Edisi keempat Jilid 1, Jakarta: PT Indeks.

Maretha, V., dan Engkos A.K. (2011). Pengaruh Store Atmosphere dan Store Image Terhadap Keputusan Pembelian Konsumen di Toko Buku Gramedia Pondok Indah. Binus Business Review, Vol. 2, No 2, Hal. 979-991.

Ma'ruf, Hendri. (2005). Pemasaran Ritel. Jakarta: PT. Gramedia Pustaka Utama.

Nurirfani, L. (2014). Pengaruh Suasana Toko dan Harga Terhadap Keputusan Pembelian Konsumen Matahari Departement Store. Jurnal Manajemen dan Bisnis Sriwijaya, Vol. 13, No. 1.

Peter, J, P., dan Olson, J. C. (2009). Consumer Behaviour. Edisi Kelima, Jilid 2. Jakarta: Erlangga. Sopiah dan Syihabudhin. (2008). Manajemen Bisnis Ritel, Cetakan ke-1. Yogyakarta: Penerbit Andi. Sugiyono. (2014). Metode Penelitian Manajemen. Bandung: Alfabeta.

Utami, C. W. (2006). Manajemen Ritel: Strategi dan Implementasi Ritel Modern. Jakarta: Salemba Empat. Utami, Christina Widhya. (2008). Manajemen Barang Dagangan dalam Bisnis Ritel. Jakarta: Bayumedia Vinci, Maharani. (2009). Manajemen Bisnis Eceran. Bandung: Sinar Baru Algensido.

Widyanto, Achmad Indra, Edy Yulianto, dan Sunarti. (2014). Pengaruh Store Atmosphere Terhadap Keputusan Pembelian (Survei pada Konsumen Distro Planet Surf Mall Olympic Garden Kota Malang). Jurnal Administrasi Bisnis, Vol. 14, No. 1, Hal. 1-6

Winardi. (2010). Kepemimpinan dan Manajemen. Jakarta: PT Rineka Cipta.

Yudatama, A., Saryadi, dan Susanto, H. (2012). Pengaruh Store Image, Store Atmospherics, Store Theatrics, dan Social Factors Terhadap Pembelian Tidak Terencana. Jurnal Ilmu Administrasi Bisnis, Vol. 1, No. 1, Hal. 1-10 